\title{
STOP, LOOK AND LISTEN: PREMERGER \\ NOTIFICATION UNDER THE HART- SCOTT-RODINO ANTITRUST IMPROVEMENTS ACT
}

\section{INTRODUCTION}

Enforcement of the antitrust laws prohibiting anticompetitive inergers has, for many years, played a significant role in the government's antitrust efforts. Yet, from the beginning, regulation of anticompetitive inergers has been inarred by a critical flaw: the ineffectiveness of post-acquisition relief. Despite the government's impressive courtroom victories, the defeated defendant corporation has often inanaged to retain the fruits of an unlawful inerger. Effective antitrust enforceinent will be possible only when the government is able to obtain preliminary injunctions prior to the consummation of unlawful mergers. It was im an atteinpt to provide a inechanisn for obtaining preliminary injunctions that the Hart-Scott-Rodino Antitrust Improveinents Act of $1976^{1}$ was passed. ${ }^{2}$ Under the Act and its accompanying regula-

THE FOLLOWING CITATIONS WILL BE USED IN THIS NOTE:

Senate Comm. ON THE Judiciary, The ANTTrRUSt Improvements ACt of 1976 Part I, S. ReP. No. 803, 94th Cong., 2d Sess. (1976) [hereinafter cited as SENATE RePort ParT 1];

SeNate COMm. ON THE Judiciary, The ANTITRUST IMPROVEMENTS ACT OF 1976 PART II, S. Rep. No. 803, 94th Cong., 2d Sess. (1976) [hereinafter cited as SENATE Report Part II];

House COMm. ON THE JUdiciary, ANTITRUst PRemerger Notification ACt, H.R. Rep. No. 1373, 94th Cong., 2d Sess. (1976), reprinted in [1976] U.S. CODE CONG. \& AD. News 2637 [hereinafter cited as HOUSE REPORT];

Merger Oversight and H.R. 13131, Providing Premerger Notification and Stay Requirements: Hearings on H.R. 13131 Before the Subcomm. on Monopolies and Commercial Law of the House Comm. on the Judiciary, 94th Cong., 2d Sess. (1976) [hereinafter cited as House Hearings];

The Antitrust Improvements Act of 1975 Part I: Hearings on S. 1284 Before the Subcomm. on Antitrust and Monopoly of the Senate Comm. on the Judiciary, 94th Cong., lst Sess. (1975) [hereinafter cited as Senate Hearings Part $\Pi$;

The Antitust Improvements Act of 1975 Part II: Hearings on S. 1284 Before the Subcomm. on Antitrust and Monopoly of the Senate Comm on the Judiciary, 94th Cong., lst Sess. (1975) [hereinafter cited as Senate Hearings Part II;

The Antitrust Improvements Act of 1975 Part III: Hearings on S. 1284 Before the Subcomm. on Antitrust and Monopoly of the Senate Comm. on the Judiciary, 94th Cong., 2d Sess. (1976) [hereinafter cited as Senate Hearings Part III].

1. Pub. L. No. 94-435, 90 Stat. 1390 (codified at 15 U.S.C. \& 18a (1976)) (the "Act"). The Act was the result of several years of congressional efforts to deal with premerger notification. Premerger notification provisions were passed by the House during the 84th Congress and were approved by the Senate Judiciary Committee of the 84th Congress, the House Judiciary Commit- 
tions (the New Rules), ${ }^{3}$ advance notice of plans for large mergers must be given to federal antitrust authorities, and consummation of the merger must be delayed for a stipulated period of time. ${ }^{4}$

This Note examines the most recent premerger notification program and compares it with earlier programs administered by the Federal Trade Cominission (FTC). Significant differences are analyzed in the context of two criteria: first, the benefits in terms of more effective antitrust enforceinent under the new program; and second, the disadvantages of the program, especially the burdens imposed on normal busmess operations.

Antitrust enforcement should improve under the new program because agencies are provided with an opportunity to secure preliminary injunctions against unlawful mergers. This is due largely to the waiting period that must be observed between the time a proposed transaction is reported and the consummation of that transaction. At the same time, the new program creates problems by requiring an unnecessarily large number of transactions to be reported, threatening procompetitive mergers with deadly delay and raising questions concerning the confidentiahity of reported material. These problems are explored and solutions are proposed for assuring the antitrust benefits of the new program while, at the same time, diminishing the hardships created.

\section{The Old Premerger Notification Program}

Premerger notification programs were established in response to congressional recognition of the fact that post-acquisition relief is seldom adequate in an antitrust context. Once an illegal merger is con-

tee of the 85th Congress, and the Antitrust and Monopoly Subcommittee of the Senate Judiciary Committee on three prior occasions. President Eisenhower urged adoption of premerger notification legislation in five successive messages to Congress. Such legislation was also supported by attorneys general Herbert Brownell and Robert Kennedy. Senate RePort.PART I 65 n.28.

2. House REPORT 5.

The government will ... have a meaningful chance to win a premerger mjunctionwhich is often the only effective and realistic remedy against large, illegal mergersbefore the assets, technology, and management of the merging firms are hopelessly and irreversibly scrambled together, and before competition is substantially and perhaps irremediably lessened, im violation of the Clayton Act.

Id. See Goolrick, The End of the "Midnight Merger": An Overview of the New FTC Premerger Notice Rules, 34 Bus. LAw. 63, 64 (1978).

3. 43 Fed. Reg. 33,537 (1978) (to be codified in 16 C.F.R. $\$ \$ 801-803$ ). Later corrections to the Notification and Report Form are reported at 43 Fed. Reg. 34,443 (1978).

"Companies required to comply with the requirements of the new premerger notification program, which fail or decline to do so, are not reheved of their obligations to comply with the requirements of the existing premerger notification program." Id. 28,045, 28,046.

4. 15 U.S.C. $\S 18$ a (1976); 43 Fed. Reg. 33,537 (1978) (to be codified in 16 C.F.R. $\$ \$ 801-$ 803). See notes 19-27 infra and accompanying text. 
summated, five or six years are often required to obtain a final divestiture order. ${ }^{5}$ During this time the acquiring company reaps illegal profits; the assets, manageinent and technology of the two inerged companies become commingled; key einployees inay be lost; and goodwill related to the acquired company inay vanish. ${ }^{6}$ Thus, although the Justice Department ultimately prevails in approximately ninety percent of all section $7^{7}$ non-bank merger cases that go to trial on the merits, ${ }^{8}$ these victories are often illusory.

Both Congress and the courts have emphasized that section 7 of the Clayton Act is designed to lialt monopolies and restraints of trade in their imcipiency, before they ripen imto full-scale Sherman Act violations. ${ }^{9}$ Yet, without advance notice of an impending inerger and without the acquisition of data relevant to a determination of its legality, it is extremely difficult for the government to carry the burden of proof required to obtain a preliminary injunction agaimst an unlawful merger. It was in an attempt to assist antitrust enforcement officials in obtaining preliminary mjunctions that a merger notification program (the Old Rules) was imtiated by the FTC on May 6, $1969 . .^{10}$ The program was expanded by resolutions in 1972, 1973 and $1974 .{ }^{11}$

In general, the Old Rules required that "companies" 12 meeting or exceeding the statutory dollar criteria ${ }^{13}$ and planning to merge with or

5. Senate Hearings Part I 148. The statement of Ralph Nader and Mark Green refers to a study by Professor Kenneth Elzinga, which found that an average of 63.8 months elapsed between the time of an illegal merger and a final divestiture order.

6. See SenAte Report PARt I 7; Senate Hearings Part I 96 (statement of Thomas Kauper); Senate Hearings Part II 546 (statement of John Flynn); Note, Preliminary Relief for the Government Under Section 7 of the Clayton Act, 79 HARV. L. REv. 391,392 (1965). In his testimony before a House committee, Paul Rand Dixon, acting chairman of the FTC, recalled a challenge to Procter \& Gamble's acquisition of Clorox. Procter \& Gamble paid \$20 million for the assets of Clorox. The FTC immediately challenged the merger. Before the challenge was resolved Clorox had earned $\$ 60$ million for Procter \& Gamble, and the company was subsequently sold for $\$ 300$ to $\$ 400$ million. House Hearings 43 (statement of Paul Rand Dixon).

7. Clayton Act, $\$ 7,15$ U.S.C. $\S 18$ (1976).

8. SENATE RePort Part I 8.

9. S. REP. No. 1775, 81st Cong., 2d Sess. 4-5 (1950) ("The intent here . . . is to cope with monopolistic tendencies in their mcipiency and well before they have attained such effects as would justify a Sherman Act proceeding"). See generally Brown Shoe Co. v. United States, 370 U.S. 294 (1962).

10. 34 Fed. Reg. 7,592 (1969). See generally House Hearings 100 (statement of Willard F. Mueller).

"This program exists in addition to special FTC notification programs applicable to the cement and food distribution industries, as well as numerous FTC orders requiring advance FTC approval of acquisitions by particular companies." House Hearings 118 (statement of James M. Johnstone).

11. See 39 Fed. Reg. 35,717 (1974); 38 Fed. Reg. 5,513 (1973); 37 Fed. Reg. 7,951 (1972).

12. 39 Fed. Reg. $35,717,35,717$ (1974). See text acconupanying note 33 infra.

13. 39 Fed. Reg. $35,717,35,717$ (1974). See text accompanying note 41 infra. 
acquire assets or stock of another corporation notify the FTC of the proposed transaction prior to consummation and file premerger Special Report forms. ${ }^{14}$ The rules specifically stated that the "procedure should not be interpreted to mean that companies must request Commission approval prior to the consummation of any transaction ...."1s Failure to file the Special Report at the time designated by the rules constituted default, subjecting the violator to penalties. ${ }^{16}$

Despite the laudable objectives of the Old Rules, they proved inadequate to prevent the consummation of unlawful mergers. The FTC was still forced to rely on post-acquisition relief, ${ }^{17}$ and the task of unscraunbling the merger and restoring the acquired company to its former status as an independent competitor was difficult at best and frequently impossible. The primary fault of the Old Rules was the absence of any express requirement that the inerger be held in abeyance while the FTC reviewed the transaction for potential anticompetitive effects. An illegal acquisition could proceed once the requisite form had been filed with the FTC, leaving the government to rely on postacquisition remedies. It was in this context that the new premerger notification program emerged.

\section{The New Premerger Notification Program}

The purpose of the new program has been described as twofold: first, to provide antitrust enforcement agencies with sufficient inforınation about proposed acquisitions to enable them to make a preliminary determination of whether a particular transaction may violate the antitrust laws; and, second, to provide the agencies with a reasonable opportunity to seek preliminary injunctions against the consummation of unlawful transactions. ${ }^{18}$

14. 39 Fed. Reg. $35,717,35,717$ (1974). See text accompanying notes $59-60$ infra.

15. 39 Fed. Reg. $35,717,35,718$ (1974).

16. I TRADE Reg. ReP. (CCH) I 4540, at $6932-41$ (Oct. 14, 1974). See text accompanying notes 64-65 infra.

17. See House Hearings 88 (statement of Eleanor M. Fox); House Hearings 175 (table of acquisitions challenged by the FTC, 1969-76, comparing date of complaint and date of acquisition).

18. Pfunder, A Basic Guide to Premerger Notification, 1 Antitrust 3 (Summer 1978).

The effective date of the New Rules was September 5, 1978. 43 Fed. Reg. 34,443, 34,443 (1978). The Act provided that it would become effective 150 days after enactment, except for the rulenaking provisions. Because final rules could not be promulgated prior to the effective date of the Act (Feb. 27, 1977), the FTC, with the concurrence of the Assistant Attomey General, promulgated a Transitional Rule, 16 C.F.R. $\& 800.1$ (1978), which was in effect until September 5, 1978. 
A. Overview.

In general, the new program requires that "persons" 19 meetimg or exceeding a statutory "size of person" test ${ }^{20}$ who wish to acquire voting securities or assets in quantities meetmg or exceedmg a statutory "size of transaction" test ${ }^{21}$ must report their imtentions prior to such acquisitions and provide information relevant to the transaction to the Antitrust Division of the Justice Department and to the FTC.22 Notification is defined as substantial completion of the Notification and Report Form promulgated by the FTC. ${ }^{23}$ After reporting, such "persons" must observe a stipulated waitmg period before consummating the transaction. ${ }^{24}$ This waiting period may be extended by a request froin either enforcement agency for additional information or documentary material. ${ }^{25}$ The Act exempts eleven classes of transactions from its requirements, ${ }^{26}$ and the FTC rules and regulations provide further exemption guidelines. ${ }^{27}$

When either enforcement agency files a motion in United States district court seeking a preliminary mjunction to prevent consummation of an acquisition, the Act requires that the court hold an expedited hearing. ${ }^{28}$ Civil penalties for failure to comply with the Act are also provided. ${ }^{29}$ In addition, the New Rules state that any device for avoiding the Act's requirements will be disregarded. ${ }^{30}$ A disclosure exemption protects the information and documents supplied by "persons",

19. 15 U.S.C. $\$ 18 \mathrm{a}$ (1976). See notes $35-40$ infra and accompanying text.

20. 15 U.S.C. \& 18a(a)(2)(A)-(C) (1976). See text accompanying notes $45-46$ infra.

21. 15 U.S.C. \& 18a(a)(3) (1976). See text accompanying notes 47-49 infra.

22. 15 U.S.C. $\$ 18 \mathrm{a}(\mathrm{d})$ (1976).

23. 43 Fed. Reg. $34,443,34,443-53$ (1978) (to be codified in 16 C.F.R. $\$ 803.1$ ).

24. 15 U.S.C. \& 18a(b) (1976). See notes 53-55 infra and accompanying text.

25. 15 U.S.C. \& 18a(e) (1976). See text accompanying notes 56-57 infra.

26. 15 U.S.C. $\S 18 \mathrm{a}(\mathrm{c})$ (1976). A number of exemptions are related to federal statutes that provide antitrust protection for certain classes of transactions. There are also exemptions for goods acquired in the ordinary course of busimess, acquisitions of non-voting securities, acquisitions by companies already owning at least $50 \%$ of the issuer's outstanding voting securities, certain acquisitions solely for investınent purposes, acquisitions that do not increase the acquiring company's percentage of ownership, and acquisitions by institutional investors that will be held solely for investment purposes.

27. 43 Fed. Reg. 33,537, 33,544-58 (1978) (to be codified in 16 C.F.R. $\S 802$ ). Exemptions are available for transactions that are not likely to involve antitrust law violations, such as stock splits, pro rata stock dividends, intra-person transactions and acquisitions of convertible voting securities.

28. 15 U.S.C. \& 18a(f) (1976). See text accompanying note 73 infra.

29. 15 U.S.C. \& $18 \mathrm{a}(\mathrm{g})(1976)$. See text accompanying note 66 infra.

30. 43 Fed. Reg. 33,537, 33,544 (1978) (to be codified in 16 C.F.R. $\$ 801.90$ ). "Any transaction(s) or other device(s) entered into or employed for the purpose of avoiding the obligation to comply with the requirements of the act shall be disregarded, and the obligation to comply slall be determined by applying the act and these rules to the substance of the transaction." Id. 
from disclosure under the Freedom of Information Act, ${ }^{31}$ except when the information would be relevant to an administrative or judicial proceeding. ${ }^{32}$

\section{B. Specific Provisions.}

Despite basic similarities, the new program differs significantly froin the Old Rules. Before evaluatimg the potential benefits and disadvantages of the New Rules, it would be beneficial to identify the basic differences between the two programs.

1. Scope of Coverage. Under the old notification program, responsibility for filing lay with a "company" that had control over any party to an acquisition that satisfied the statutory dollar criteria. The term "company" referred to the pretransaction, ultimate parent company of the acquiring or the acquired party, together with all wholly or partially owned subsidiaries of the acquired or acquiring company in which the parent company had an ownership interest. ${ }^{33}$ Two alternative criteria were used to define "ownership imterest": "either (1) holding a majority of the outstanding voting stock, or (2) holding the power to formulate, determine, or veto basic busmess decisions through the use of dominant stockholding rights, proxy voting, contractual votimg arrangements, agents, or other means." 34

The new program employs a much more complex test im assigning responsibility for notifying the FTC and the Antitrust Division. Under the Act and the New Rules, the identity of the "acquiring person" and the "acquired person" must be ascertained. ${ }^{35}$ In order to identify the "acquiring person," it is first necessary to determine which entity ${ }^{36}$ will have beneficial ownership of the assets or votimg securities to be acquired. This entity's "ultimate parent entity" is then determined by applymg an objective definition of control: ${ }^{37}$ "either (1) holding 50

31. 5 U.S.C. \& $552(1976)$.

32. I5 U.S.C. \& 18a(h) (1976). See text accompanying notes 71-72 infra.

33. 39 Fed. Reg. $35,717,35,717$ (1974).

34. Id.

35. 43 Fed. Reg. 33,537, 33,539 (1978) (to be codified in 16 C.F.R. § 801.2).

Any person which, as a result of an acquisition, will hold voting securities or assets, either directly or indirectly, or through fiduciaries, agents, or other entities acting on behalf of such person, is an acquiring person.

...

- - [T]he person(s) within which the entity whose assets or voting securities are Id.

being acquired is included, is an acquired person.

36. See 43 Fed. Reg. 33,537 (1978) (to be codified in 16 C.F.R. $§ 801.1(\mathrm{a})(2)$ ) for the definition of an "entity."

37. The original definition proposed by the FTC was a strict subjective test focusing on effec- 
percent or more of the outstanding voting securities of an issuer; or (2) having the contractual power presently to designate a majority of the directors of a corporation, or $\mathrm{m}$ the case of unincorporated entities, of individuals exercising similar functions." 38 The "acquiring person" consists of the ultimate parent entity and all entities under its direct or indirect control. ${ }^{39}$ A similar approach is used to identify the "acquired person," except that here it is necessary to determine which entity had beneficial ownership of the assets or was the issuer of any voting securities to be transferred $\mathrm{m}$ the relevant transaction. ${ }^{40}$

One of the more significant changes instituted under the new program involves the dollar anount that is necessary to trigger the filing requirement. Under the Old Rules, notification was required for those mergers and acquisitions im which a company with total sales or assets of $\$ 10$ million or more was acquired by another company and the total combimed sales or assets of the two companies exceeded $\$ 250$ million. If a nonmanufacturing company was acquired, only assets were considered for purposes of applying the dollar criteria. ${ }^{41}$

On the other hand, the Act sets forth three conditions that must be met in order to trigger the filing requirement. ${ }^{42}$ First, the Act requires that either the acquiring person or the acquired person be "engaged in commerce or in any activity affecting commerce." 43 The New Rules have expanded this "commerce test" in accordance with the definitions of acquiring and acquired persons so that the test is satisfied "if any entity mcluded within the acquiring person, or an entity mcluded within the acquired person, is engaged in commerce or in any activity affecting commerce." 44

Second, filing will be required only in those transactions in which a specified "size of person" test is met. ${ }^{45}$ This test is satisfied if one of the companies imvolved in the transaction has annual net sales or total assets of $\$ 10$ million or more and the other company has annual net

tive control. The proposal was made in recognition of the fact that ownership of only a small percentage of the outstanding stock inay be sufficient to control a large corporation. However, business lobbyists attacked this definition as being open to widely varying interpretations. As a result, busmess was able to persuade the FTC to adopt the more objective standard finally included in the New Rules. This change has been praised as the "biggest busmess victory" in the New Rules. Bus. WeEK, Oct. 17, 1977, at 40.

38. 43 Fed. Reg. 33,537, 33,538 (1978) (to be codified in 16 C.F.R. \& 801.1(b)).

39. Id. 33,539 (to be codified in 16 C.F.R. $\$ 801.2(a)$ ).

40. Id. (to be codified in 16 C.F.R. $\$ 801.2(\mathrm{~b})$ ).

41. 39 Fed. Reg. 35,717, 35,717 (1974). See Wall St. J., July 31, 1978, at 3, col. 2.

42. 15 U.S.C. \& $18 \mathrm{a}(\mathrm{a})(1)-(3)$ (1976).

43. Id. $\$ 18 \mathrm{a}(\mathrm{a})(1)$.

44. 43 Fed. Reg. $33,537,33,539$ (1978) (to be codified in 16 C.F.R. § 801.3).

45. 15 U.S.C. \& $18 \mathrm{a}(\mathrm{a})(2)(\mathrm{A})-(\mathrm{C})(1976)$. 
sales or total assets of at least $\$ 100$ million. In the case of a person not engaged in manufacturing, only total assets are considered. ${ }^{46}$

Fimally, even if both the acquiring and acquired persons satisfy the "size of person" test, filing will not be required unless a statutory "size of transaction" test is also met. ${ }^{47}$ This test is satisfied only where the acquiring person, as a result of the acquisition, will hold fifteen percent or more of the voting securities or assets of the acquired person, or more than $\$ 15$ million of the aggregate total value of votimg securities and assets of the acquired person. ${ }^{48}$ If the "commerce," "size of person" and "size of transaction" tests are all satisfied, notification will be required except $\mathrm{m}$ those cases where the transaction is specifically exempted by the $\mathrm{Act}^{49}$ or the New Rules. ${ }^{50}$

2. The Waiting Period. Both the old and the new programs attempt to provide government officials with notification of proposed mergers prior to their consummation. The major difference is that the new program mandates a waiting period which must be observed between the time of notification and consummation of the merger. In the case of a merger or acquisition of assets, the Old Rules required filing of notification and the Special Report within ten days after any agreeinent or understanding in principle had been reached. The same deadline was applicable in the case of a stock acquisition that would result in the acquiring coinpany holding fifty percent or more of the voting stock of another company. ${ }^{51}$ The FTC, however, recognizing that it lacked the authority to enjoin inerger agreements, stated that "[i]t was not the intention of the Commission to impose any waiting period upon the consummation of a merger or acquisition." 52

46. Id. \& 18a(a)(2)(B).

47. Id. \& $18 \mathrm{a}(\mathrm{a})(3)$.

48. The Act does not define the circumstances under which voting securities or assets will be deemed to be held "as a result of" the acquisition. However, a definition is provided in section 801.13 of the New Rulcs. In general, all securities of the acquired person that will be held by the acquiring person aftcr the transaction will be held "as a result of" the acquisition, including all such securities that were held by the acquiring person immediately prior to the transaction. With respect to assets, the general rule is that all assets to be acquired from the acquired person will be held "as a result of" the acquisition. In addition, for the purpose of determining the dollar value of the assets (but not the percentage of assets), any assets acquired from the same acquired person within 180 days prior to the signing of any agreement to acquire additional assets will be regarded as part of the assets held "as a result of" the acquisition, if such prior assets are held by the acquiring person immcdiately following the transaction. 43 Fed. Reg. 33,537, 33,541 (1978) (to be codificd in 16 C.F.R. $\$ 801.13$ ).

49. See note 26 supra.

50. See note 27 supra.

51. 39 Fed. Reg, 35,717, 35,718 (1974).

52. 1 Trade Reg. Rep. (CCH) I 4540, at 6941 (Oct. 14, 1974). 
However, a waitimg period is included in the new premerger notification prograin. The most important provision of the New Rules states that no company nay consummate a transaction to acquire, either directly or indirectly,,$^{53}$ any voting securities or assets of another company unless both coinpanies have filed the rcquisite notice and the statutory waiting period has expired. The waiting period begims to run on the date notification is received by both the FTC and the Antitrust Division and ends thirty days later. A partially completcd notification will be sufficient to trigger the waitimg period if accompanied by a statement of valid reasons for noncomphiance. ${ }^{54}$ In certain cases, the Act permits either enforcenient agency to terminate the waitmg period prior to its expiration..$^{55}$

Both the Act and the New Rules vest the FTC and the Antitrust Division with the power, prior to expiration of the thirty-day waitmg period, to require the submission of additional information by any person required to file notification, or any officer, director, partner, agent or einployee of such a person. ${ }^{56}$ The waiting period continues in effect during the time such a request remains outstanding. Furthermore, a request for additional information extends the waiting period for twenty days beyond the date that the additional information is received. Further extensions are available only by court order and only in situations where the parties have failed substantially to coinply with the requirenients of the Act. ${ }^{57}$

3. The Notification Forms. The notification form provided under the New Rules calls for more detailed information and is "significantly different" fron the old Special Report form. ${ }^{58}$ Under the Old Rules,

53. Unlike the Old Rules, the New Rules clearly state that secondary acquisitions will be regarded as independent transactions and the premerger notification and waiting period requirements must be satisfied for these secondary acquisitions as well as for the primary acquisitions with which they are associated.

Whenever as a result of an acquisition (the "primary acquisition") an acquiring person will obtain control of an issuer which holds voting securities of another issuer which it does not control, then the acquisition of the other issuer's voting securities is a secondary acquisition and is separately subject to the act and these rules.

43 Fed. Reg. 33,537, 33,539 (1978) (to be codified in 16 C.F.R. $\$ 801.4(a)$ ).

54. 15 U.S.C. $\$ 18 \mathrm{a}(\mathrm{b})(1)(\mathrm{A})(\mathrm{ii})(1976)$. See note 63 infra and accompanying text.

55. 15 U.S.C. $\$ 18 \mathrm{a}(\mathrm{b})(2)$ (1976) specifies that notice mnst be published in the Federal Register if neither the FTC nor the Antitrust Division imtends to take any action with respect to a particular acquisition within the statutory waiting period.

56. 15 U.S.C. $\S 18 \mathrm{a}(\mathrm{e})(1)(1976) ; 43$ Fed. Reg. 33,537, 33,550-51 (1978) (to be codified in 16 C.F.R. $\S 803.20$ ).

57. 15 U.S.C. $\$ 18 \mathrm{a}(\mathrm{e})(2)$ (1976).

58. The reporting form proposed by the FTC is significantly different from the form currently used by the FTC in its more limited premerger notification program. In addition to requesting data about the sales, assets, and product lines of the reporting compa- 
proper notification consisted of letters and Special Reports submitted to the FTC by all companies participating in the transaction. The letters identified the company, indicated whether the coinpany was an affiliate or subsidiary of another coinpany and described the type of proposed transaction, including such terms as the assets and/or stock to be acquired, the estimated dollar value of the transaction, the date of agreement and the anticipated date of consummation. If the proposed transaction was not completed, the FTC was to be notified of this development. ${ }^{59}$

The Special Report form required detailed information. Information identifying all relevant companies, as well as their affiliates and subsidiaries, and describing the inarmer in which the transaction was to be carried out and all stock or assets to be transferred was to be included. In addition, data concerning the types of products manufactured and sold along with the corresponding dollar value, and a description of any mergers, acquisitions or disposals made by the company simce January 1, 1961, were to be submitted to the FTC. In an attempt to ensure the accuracy of the information reported, the Old Rules required that each Special Report form be certified and sworn to by an official of the reporting coinpany. ${ }^{60}$

While the old form merely required a description of all stock or assets to be transferred, notification under the New Rules must mclude a description of each class of voting securities outstanding after the acquisition, the identity of each person acquiring any securities of any class and the total number and percentage of each class of securities that will be held by the acquiring person upon consummation of the transaction. Shareholders of the person filing the notification form, as well as the holdings of the person filing, nust be identified. Copies of certain specified Securities and Exchange Commission (SEC) filings for the past three years must be submitted, mcluding the inost recent proxy statement and all registration statements. ${ }^{61}$ In addition, all "studies, surveys, analyses and reports" prepared by the parties to the transaction for the purpose of evaluating the merger inust be furmished if they relate to "market shares, competition, coinpetitors, markets, potential for sales growth or expansion into product or geographic inarkets."62

Much of the required information will be repetitive, such as the

nies, the proposed form requires information which would tend to show anticompetitive horizontal, vertical and conglomerate relationships among the parties to the transaction.

Mergers AND ACQuisitions, Spring 1977, at 46.

59. 39 Fed. Reg. 35,717, 35,717 (1974).

60. 1 Trade Reg. Rep. (CCH) If 4540, at 6932-41 (Oct. 14, 1974).

61. 43 Fed. Reg. $34,443,34,447$ (1978) (to be codified in 16 C.F.R. $\S 803$ ).

62. Id. 
"description of voting securities to be acquired" and the SEC filings, thereby diminishing the hardship businesses inay face in coinplying with the statute. Furthermore, a person who is unable to supply a coinplete response to any itein on the form inay file a statement of reasons for noncompliance. ${ }^{63}$ At any rate, the detailed information required on the new form does not seem unreasonable. The additional information will be useful in evaluating the anticompetitive effects of a inerger, especially where there are conglomerate relationships among the parties.

4. Penalties for Noncompliance. One change instituted under the New Rules that seems likely to produce positive results in terms of inore effective antitrust enforcement is the penalty for noncoinpliance. Under the Old Rules, failure to file the Special Report form at the designated time constituted default. ${ }^{64}$ If the report was not filed within thirty days after notice of such default, the coinpany would be penalized $\$ 100$ per day for so long as the default continued. ${ }^{65}$

In contrast, any person failing to coinply with the provisions of the new Act inay be subject to a civil penalty of $\$ 10,000$ for each day the violation continues. ${ }^{66}$ The significance of this tremendous increase in potential liability becomes apparent when one realizes that a corporation may derive as inuch as $\$ 10$ million in profits for each year that the illegally acquired company is retained. ${ }^{67}$ While a penalty of $\$ 10,000$ per day inay not always deprive the acquiring coinpany of the total profits of an unlawful acquisition, it should certainly provide a more effective deterrent than the mere $\$ 100$ per day penalty for default under the Old Rules.

Some relief froin the harshness of the new penalties may be available if the courts hiberally interpret the term "substantial compliance." In the absence of substantial compliance with the notification requireinents of the Act and the New Rules, a United States district court may order coinphiance and inust extend the waiting period until the parties are found to be in substantial coinpliance with the Act. ${ }^{68}$ The extent to which "substantial coinphiance" as opposed to total complance will be available to busmesses for purposes of avoiding civil hability while, at the same time, withholding a portion of the notification information

63. 15 U.S.C. $\$ 18 \mathrm{a}(\mathrm{b})(1)(\mathrm{A})(\mathrm{ii})$ (1976) requires a statement of reasons for noncompliance. The guidelines for the contents of such a statemeut are set forth at 43 Fed. Reg. 33,548 (1978) (to be codified in 16 C.F.R. $\$ 803.3$ ).

64. 1 TRADE REg. ReP. (CCH) ๆ 4540, at 6930 (Dec. 12, 1978).

65. 15 U.S.C. $\$ 50$ (1976); see House Hearings 88 (statement of Eleanor M. Fox).

66. 15 U.S.C. $\& 18 \mathrm{a}(\mathrm{g})(1)$ (1976).

67. See text accompanying note 75 infra.

68. 15 U.S.C. $\& 18 \mathrm{a}(\mathrm{g})(2)$ (1976). 
will depend on the interpretation given to the phrase "substantial coinpliance" by the courts.

A liberal interpretation of "substantial compliance" would afford the greatest proteetion to the rights of the government as well as those of the parties to the proposed merger. All of the equities of the particular situation should be considered. If information is withheld by the parties for frivolous or improper reasons, this should not constitute "substantial compliance." On the other hand, failure to coinply with a government request for additional information of questionable relevance or for information that cannot be compiled by the parties within a reasonable period of time slould not constitute failure to comply substantially with the requirements of the Act.

5. Disclosure. A significant change under the New Rules involves the confidentiality of the notification of a proposed transaction and the information submitted on and with the notification form. The Old Rules stated that the notification was to be made a "part of the public record." 69 It would appear, however, that the disclosure provision was intended to apply only to the notification itself and not to the Special Report form. In fact, the absence of a similar provision with respect to Speeial Reports indicated that the drafters intended to exempt this material froin disclosure. The importance of such a limitation becomes apparent when it is recalled that the nost important corporate information was contained in the Special Report, rather than the notification letter. ${ }^{70}$

Unlike the Old Rules, the Act provides that any information and documentary material filed with the FTC and the Antitrust Division pursuant to the Act will be exempt from disclosure under the Freedom of Information Act. ${ }^{71}$ The exemption will not be available, however, in cases where the inaterial is relevant to an administrative or judicial proceeding. Furtliermore, the right of Congress to obtain access to information filed under the Act is explicitly reserved. ${ }^{72}$

6. Preliminary Relief. Finally, the Act is novel in its treatment of preliminary injunction proceedings instituted on the basis of information obtained through the notification process. If either the FTC or the Antitrust Division files a motion seeking a preliminary injunction against consummation of a proposed acquisition pendente lite, alleging

69. 39 Fed. Reg. 35,717, 35,717 (1974).

70. See text accompanying note 60 supra.

71. 5 U.S.C. \& 552 (b)(4) (1976).

72. 15 U.S.C. $\& 18 \mathrm{a}(\mathrm{h})(1976)$. 
that consummation of the proposed acquisition will constitute a violation of the antitrust laws and certifying to the United States district court that the public interest requires relief pendente lite, then a district judge will immediately be designated to hear the action, and the notion for preliminary injunction will take precedence over most other matters. ${ }^{73}$

\section{IMPACT OF THE NEW Rules}

Acclaim for the new premerger notification program has been widespread. Cases similar to United States v. El Paso Natural Gas $\mathrm{Co}^{74}$ will provide the most striking examples of the benefits to be expected under the new program. In that case, a divestiture order was obtained only after seventeen years of hitigation and six United States Supreine Court decisions. El Paso Natural Gas Company derived profits of approximately $\$ 10$ million for each year that it retamed the illegally acquired company. ${ }^{75}$ David K. Watkiss, chief counsel for the ultimately successful applicant in the El Paso divestiture proceeding, supported the new premerger notification program, stating: "If a preinerger notification requirement like the one proposed had been on the books 20 years ago, I would probably never have had this interesting experience, but more importantly, the public and the courts would have been spared the ordeal of the El Paso case." 76

Despite the apparent need for inore effective antitrust enforcement tools, the new prenierger notification program has not gamed universal acceptance. ${ }^{77}$ The inajor source of conflict is a series of studies confirming a decline in merger activity in recent years. ${ }^{78}$ Opponents of the new prograin cite such studies in support of the argument that new

73. Id. § 18a(f). See Comment, The Goal of the New Premerger Notification Requirements: Preliminary Relief Against Anticompetitive Mergers, 1979 DUKE L.J. 249.

74. 376 U.S. 651 (1964).

75. SENATE Report PART I 70.

76. House Hearings 58 (statement of David K. Watkiss).

In United States v. Amax, Inc., 402 F. Supp. 956, 958 (D. Conn. 1975), Amax agreed to postpone the closing of a proposed inerger pending the outcome of an expedited trial. There was a four-day trial and the case was concluded within two inonths after the filing of the coinplaint. The contrast with $E I$ Paso has been noted: "The $A M A X$ precedent is exemplary, and shows how the $E I$ Paso problems can be avoided even under present law." House Hearings 78 (statement of Eleanor M. Fox).

77. "It is difficult to understand why the Hart-Scott-Rodino Antitrust Improvements Act should receive support from any American interested in the future of business and employment in this country." N.Y. Times, Oct. 24, 1976, \& 3, at 7, col. 6 (letter from Martin B.C. Sinpson). See also House Hearings 185 (letter fron United States Chamber of Commerce).

78. SenATE RePORT PART II 214-15. There were approximately 4,500 inergers in $1969 \mathrm{com}$ pared with approximately 1,750 in 1974. House Hearings 3 (statement of Thomas Kauper). 
enforcement mechamisms are not needed. ${ }^{79}$ Others argue that it would be a gross error to interpret such a decline im merger activity as eliminatimg the need for a more effective program of notification. ${ }^{80}$ Still others contend that plans for acquisitions are widely publicized, thereby providing the antitrust enforcement agencies with ample opportunity to resist unlawful mergers prior to consummation of the transactions. ${ }^{81}$ Eacli of these argunients was advanced during the debates over the new premerger program. However, in the end, the historical futility of post-acquisition remedies served to tip the balance in favor of the new premerger notification program.

In evaluating the probable consequences of the changes effected under the New Rules, two factors should be considered: first, the New Rules should be judged on the basis of their contribution to more effective antitrust enforcement; and second, the disadvantages, particularly the burdens imposed on government and busmess, should be weighed against any potential benefits.

\section{A. Threshold Levels for Reporting Companies.}

Jurisdiction is broader under the new premerger notification program and, consequently, encompasses a larger number of transactions. Under the Old Rules, "companies" were required to report to the FTC. ${ }^{82}$ The Act and the New Rules require that notification be filed by "persons."83 Thus, transactions involving natural persons as well as corporations, partnerships and foreign governments are included. The more inclusive tern, "person," was used to expand the new premerger notification progran to include transactions involving certaim non-corporate actors regulated under section 5 of the Federal Trade Commission $\mathrm{Act}^{84}$ and to include mergers open to challenge under the Sherman Act, whicli contaims no restriction based on the legal structure of the merging parties. ${ }^{85}$

Expanding the coverage of the Act even further, the FTC lias interpreted the Act to encompass large, incorporated joint ventures. ${ }^{86}$ Because the legislative history is not clear with respect to whether the

79. The Senate's Antitrust Follies, Wall St. J., June 2, 1976, at 18, col. 1.

80. House Hearings 102 (statement of Willard F. Mueller).

81. Id. 118 (statement of James M. Johnstone).

82. 39 Fed. Reg. 35,717, 35,717 (1974). See text accompanying notes 33-34 supra.

83. 15 U.S.C. \& 18a(a) (1976). See notes $35-40$ supra and accompanying text.

84. 15 U.S.C. \& 45(a)(2) (1976).

85. 122 CoNG. REC. H10293 (daily ed. Sept. 16, 1976) (remarks of Rep. Rodino).

86. 43 Fed. Reg. 33,537, 33,543 (1978) (to be codified in 16 C.F.R. § 801.40). See Mergers AND ACQUisitions, Spring 1977, at 46-47. 
notification requirements should apply to joint ventures, the FTC rule has been a source of controversy. ${ }^{87}$ The FTC plans to review the rule after one year to determine whether the advance-notice requireinent should be extended to apply to unincorporated joint ventures as well. ${ }^{88}$

In addition to expanded jurisdiction, the new program sets a lower threshold level for reporting. Notification must be filed under the New Rules if one party to the transaction is valued at $\$ 10$ million or nore and the other party has a value of at least $\$ 100$ million, ${ }^{89} \mathrm{~m}$ contrast to the combined asset test of $\$ 250$ million under the Old Rules. ${ }^{90}$

Finally, the Act has been interpreted to require separate advance notice of secondary acquisitions. ${ }^{91}$ This differs from the Old Rules, which contained no reference to secondary acquisitions and were never interpreted to apply to such acquisitions. This expanded application of the New Rules recognizes the fact that an acquisition may violate the antitrust laws even thouglr it is effected inerely as a secondary consequence of the primary transaction.

The potential impact of the more extensive jurisdictional scope of the new preinerger program in terms of the increased workload imposed on antitrust enforcement agencies is one of the inajor questions arising under the Act and the New Rules. Precise figures as to the number of additional reports required under the new program are not available. However, it lias been estimated that between 100 and 150 inergers each year will qualify under the "size of person" test of the Act. ${ }^{92}$ Thus, between thirty-five and sixty-one additional mergers will be reported each year under the new program than were reported under the $\$ 250$ million criteria of the Old Rules. ${ }^{93}$ The significance of the additional reports will depend upon three factors: first, the likehhood that the additional reported mergers will have anticompetitive effects; second, the burden imposed on the FTC and the Antitrust Division im evaluatimg the additional reports within a short period of time; and finally, the effect of more frequent reporting on the business community.

87. See Merger Notification Business Can Live With, Bus. WeEk, Oct. 17, 1977, at 40.

88. See Mergers AND ACQuisitions, Spring 1978, at 30; Wall St. J., July 31, 1978, at 3, col. 2.

89. 15 U.S.C. $\$ 18 \mathrm{a}(\mathrm{a})(2)(A)-(C)$ (1976). See text accompanying notes $45-46$ supra.

90. 39 Fed. Reg. $35,717,35,717$ (1974). See text accompanying note 41 supra.

91. 43 Fed. Reg. 33,537, 33,539 (1978) (to be codified in 16 C.F.R. $\$ 801.4(a)$ ). See note 53 supra.

92. Senate Report Part I 66; House Report 11; Wall St. J., July 28, 1976, at 4, col. 2.

93. House Hearings 172 (statement of Calvin J. Collier).

In other words, $29 \%$ of all FTC complaints would not have been reportable under the "size of person" test of the New Rules, whereas $62 \%$ would fail to uneet the dollar criteria of the old program. Senate Hearings Part I 511 (statement of Joseph F. Brodley). 
The argument that the lower threshold level for reporting under the new program encompasses too broad a group of transactions is persuasive. ${ }^{94}$ Clearly, the purpose of premerger notification is to provide inore effective enforcement of section 7 of the Clayton Act. However, a study conducted by the staff of the FTC prior to adoption of the New Rules revealed that, of mergers consummated between February 1972 and November 1973, a reduction of the dollar criteria from $\$ 250$ million to $\$ 150$ million would have resulted in notification of only fifteen additional transactions. Of the fifteen, only three appeared to raise any significant antitrust questions. "In any event, the three transactions were examined under estabhshed merger screening and evaluation procedures." 95 Moreover, the need for lower threshold size criteria diminishes as imflationary forces produce higher price tags on corporate transactions. According to one commentator:

[A] limit of $\$ 100$ million of assets or sales for notification and reporting purposes may be lower.than is necessary to cover most objectionable and economically significant mergers or acquisitions. Moreover, inflationary forces in the past few years appear to negate the need for lowering the $\$ 250$ million assets or sales size criteria.96

The lower threshold level of the new program is questionable not only in terms of the lack of significant anticompetitive effects resultimg from the additional reported transactions, but also in view of the burden imposed on enforcement agencies and the business community. The FTC fears that a full investigation of all mergers satisfying the "size of person" test will mean that "the fruits of [their] efforts might

94. See Senate Hearings Part III 70 (statement of Eleanor M. Fox); House Hearings 99 (statement of Willard F. Mueller); id. 193 (letter from the Association of the Bar of the City of New York).

"[T] dred million dollars in sales or assets would cover hiterally thousands of transactions which have no legally significant anticompetitive impact." Senate Hearings Part II 573 (statement of A.G.W. Biddle).

95. House Hearings 172 (letter from Calvi J. Collier).

96. Id:; Wall St. J., Mar. 10, 1977, at 1, col. 5.

There was some support for a size of transaction test even lower than the one eventually included in the new premerger program. According to the proponents of the lower threshold level, if small nergers were known to be beyond the visibility of the federal antitrust enforcement agencies, they would certainly proliferate. Senate Hearings Part $I$ 139, 143 (statement of Ralph Nader); Senate Hearings Part I 513 (statement of Joseph F. Brodley). The difficulty with this contention is that it is equally applicable to the Old Rule's $\$ 250$ million criteria. However, the evidence seems to suggest a contrary trend, with less merger activity rather than a protiferation of small mergers. Furthermore, small mergers might not serve the same busmess goals as large mergers. Finally, a series of small mergers could not be used to escape the new program's $\$ 100$. million threshold, since these small mergers would soon expand the total sales or assets of the acquiring company beyond the threshold level. 
not be worth the cost."97 The American Bar Association voiced a similar concern: "Inclusion of all such transactions is likely to deluge the antitrust authorities with meanimgless paper and immerse them in unnecessary administrative duties."98

These predictions, however, should not be accepted without question. Not all transactions satisfying the "size of person" test will have to be reported under the Act, but only those which also satisfy the fifteen percent or $\$ 15$ million "size of transaction" test. Furthermore, although every transaction that qualifies under the "size of person" and "size of transaction".tests is potentially reportable, the New Rules exeinpt all acquisitions above the fifteen percent or $\$ 15$ million level except those that satisfy certain specified "notification thresholds," provided certain timing conditions are fulfilled. ${ }^{99}$ In any event, the burden imposed on the antitrust enforcement agencies by the necessity of processing a maximuin of sixty-one additional notifications each year does not appear substantial.

The expanded jurisdictional coverage of the new premerger notification program inay also impose burdens on busmeis. Smaller businesses will now find it necessary to submit advance notice of proposed acquisitions and, since filing is required for transactions involving sinaller dollar ainounts, notification will be required more often. ${ }^{100}$ However, businesses plaiming an acquisition or merger that satisfies the statutory criteria could easily prepare the necessary reports in advance. Much of the information would appear to be readily available and would not require lengthy preparation.

A consideration of the advantages and disadvantages of the lower

97. Senate Report Part II 210-11, 216; Senate Hearings Part $171-72$ (statement of Lewis A. Engman).

98. Senate Hearings Part III 70 (statement of Eleanor M. Fox); House Hearings 79 (statement of Eleanor M. Fox).

Within four weeks of the September 5, 1978, effective date of the New Rules, more than 100 transactions had been filed with the FTC and the Justice Department. 100 Transactions Filed Under New Premerger Rules, National L.J., Oct. 2, 1978, at 3, col. 1. In the first six weeks after the rules took effect, more than 170 proposed transactions were filed. 2 Merger Experts Forecast No Slackening in Corporate Takeovers Under New Regulations, National L.J., Oct. 30, 1978, at 6, col. 2. According to the FTC, many of these filings were the unnecesary result of confusion as to the requirements of the New Rules. Approximately half of all transactions reported in the first four weeks required clarifications by the FTC, and a dozen or more were so much in error that refilings were requested. 100 Transactions, supra. Most of the unnecessary filings were a result of lawyers' carelessness in reading the rules, rather than of the complexity of the law. Id. These problems should decrease as the bar becomes more familiar with the new program and the FTC issues formal interpretations of the confusing rules.

99. 43 Fed. Reg. 33,537, 33,539, 33,545 (1978) (to be codified in 16 C.F.R. $\$ \S 801.1(\mathrm{~h}), 801.2)$.

100. See Senate Hearings Part II 573 (statement of A.G.W. Biddle); Senate Hearings Part II 1033 (letter from Edward I. O'Brien). But see Senate Report PART I 65-66 (the Act will not hamper bnsimess with undue paperwork and delay). 
threshold level for reporting indicates that the New Rules will result in slight antitrust enforcement benefits and will impose minimal burdens on the government and business commumity. The additional mergers reported under the New Rules will involve sinall dollar amounts and carry only a slight chance of significant anticompetitive impact. Retention of the old $\$ 250$ million threshold would probably have been sufficient for meanimgful enforcement of section 7 . On the other hand, the burdens of added notification are not significant. It is doubtful that the FTC or the Antitrust Division will encounter any difficulty in reviewing the sinall number of additional forms which will be filed each year. If problems should arise, a simple system of priority review could be instituted. Under such a scheme, the agency would carefully scrutinize those notifications involving the greatest probability of antitrust violations. A cursory inspection might be afforded to predictably less harmful mergers. The agency could select acquisitions requiring prompt and careful scrutiny on the basis of the dollar value of the transaction and the industry and product lines affected. ${ }^{101}$ At any rate, the lower reporting threshold need not be abandoned on the basis of the enforcement agencies' inability to handle the additional reports.

Similarly, the burden on business is not significant in a direct sense. Busmesses may file notification for any legal inerger at the earliest possible date, and those with nothing to hide may seek FTC and Antitrust Division suspension of the waitmg period. It would seem that the only potential disadvantage of the lower threshold level would be the indirect relationship it bears to other problems in the new program. The increase in the number of transactions reported and in the number of companies reporting will serve to exacerbate any other business-related disadvantage of the new premerger notification program.

\section{B. Mandatory Waiting Periods.}

The niost important innovation under the Act is the mandatory thirty-day waiting period which must be observed between agency receipt of the notification forms and consummation of the merger. The waiting period is designed to enable antitrust enforcennent officials to review the transaction for possible antitrust violations and bring suit for preliminary relief when appropriate. The waitmg period provision has been praised as the most significant and critical factor in the new

101. As of February 2, 1979, the FTC had not developed a system of priority review. "All forms [were] reviewed completely before any decision regarding Commission action [was] inade." Letter from Malcolm P. Pfunder, Assistant Director for Evaluation, FTC, to John Titus (February 2, 1979) (on file at Duke Law Journal office). 
program ${ }^{102}$-a salutary aid to antitrust enforcement. ${ }^{103}$ However, there may be certaim problems associated with the imposition of a waitimg period.

Initially, it should be noted that while the Old Rules did not explicitly require a delay between filing and consummation, in effect, a waiting period was imcluded. The old premerger program required filing of notification and Special Report forms within ten days after any agreenent in principle to inerge. ${ }^{104}$ In practice, the notification was almost always filed prior to consummation of the transaction. Thus, the Old Rules contaimed a de facto waiting period. "It [was] techincally not advance notice but it virtually always [was] advance notice because usually 10 days after the agreement im primciple [was] substantially more than 30 days before the consummation."105

The de facto waiting period theory assumes that there will always be a substantial delay between the agreement in primciple and the actual consummation of the transaction, resulting from the numerous organizational probleins involved in completing a large acquisition. While this may be true in some cases, the Old Rules did not guarantee that a waiting period would be observed. A business contemplating an unlawful acquisition could artfully postpone reaching the mythical "agreement in principle" until it virtually comcided with the closing date. Thus, any waiting period that did exist was under the complete control of the reporting firms. Despite the claim that a de facto waiting period was included in the Old Rules, it was not until the enactment of the new program that enforcement agencies could be assured of sufficient time to review data and seek preliminary relief against unlawful transactions prior to their completion.

The inandatory waiting period required under the New Rules represents the inost crucial departure from the old merger notification program. However, it is also the most widely criticized. The thirty-day mandatory delay carries with it the potential for disruptive effects within the business commumity. These adverse effects appear even more likely to occur when one considers that the waiting period may be extended for an additional twenty days by either the FTC or the Antitrust Division if either agency requests additional information or docuinentary material. ${ }^{106}$ "To accomplish this further delay, the

102. Senate Hearings Part I 81 (statement of Thomas Kauper).

103. House Hearings 79 (statement of Eleanor M. Fox).

104. 39 Fed. Reg. 35,717, 35,717-18 (1974). See text accompanying note 51 supra.

105. House Hearings 88 (statement of Eleanor M. Fox). See also id. 120 (statement of James M. Johnstone); Senate Hearings Part I 462 (statement of Arnold M. Lerman).

106. 15 U.S.C. \& 18a(e)(2) (1976); 43 Fed. Reg. 33,537, 33,551 (1978) (to be codified in 16 C.F.R. $\S 803.20(\mathrm{c})(2))$. See text accompanying notes 56-57 supra. 
Government would have to make no showing of diligence, or even of its need for the additional information." 107 The availability of such an extension inay induce government officials to request additional information for tactical reasons whenever they are unable to analyze all of the necessary data within the allotted thirty-day period but do not wish to risk allowing an acquisition to pass unnoticed if it may later be a subject of litigation. ${ }^{108}$

A further danger hes in the fact that additional information can be requested from numerous parties, some of whom may not be under the direct control of the parties involved in the acquisition. ${ }^{109}$ Thus, the persons involved may be subjected to prejudicial delay through no fault of their own. ${ }^{10}$

Criticisin of the mandatory waiting period centers on the possibility that such delay inay threaten procoinpetitive inergers and dry up the capital flow that is essential to a healthy economy. Not all inergers will affect the market in which the firms operate, and soine inerging firms may be too sinall significantly to affect coinpetition in the relevant inarket. Furthermore, mergers provide a means by which unprofitable subsidiaries and sinall, poorly inanaged corporations inay be sold, thus freeing capital for investinent in more efficient concerns. Such inergers actually proinote competition by encouraging entry into and exit from relevant markets.

Many have criticized the new program, or similar proposals, on the ground that busmess realities may require completion of a transaction within a very short period of time, possibly because of the parties' belief that the merger inust be consummated quickly in order to avoid interference by competitors or other interested parties. According to one such report: "[T]he Committee does not believe that a refusal by the government to waive the 30-day waiting period should automati-

107. Senate Report Part II 211. However, one could argue that parties need not comply with a government request for irrelevant information.

[A] Government request for material of dubious or margimal relevance, or a request for data that could not be compiled or reduced to writing in a relatively short period of time, might well be unreasonable. In these cases, a failure to comply with such unreasonable portions of a request would not constitute a failure to "substantially comply" with the bill's requirements.

1 TRADE Reg. Rep. (CCH) I 4231, at 6425-5 (Mar. 28, 1977). See Scher, Emerging Issues Under the Antitrust Improvements Act of 1976, 77 Colum. L. REv. 679, 695-97 (1977). See text accompanying note 118 infra.

108. Senate Hearings Part I 223 (statement of Richard D. Godown). Out of more than 170 proposed transactions reported to the FTC and the Justice Department in the first six weeks after the New Rules took effect, the enforcement agencies made 15 requests for additional information. 2 Merger Experts, supra note 98.

109. 43 Fed. Reg. 33,537, 33,550 (1978) (to be codified in 16 C.F.R. $\$ 803.20(\mathrm{a})(1)$ ).

110. Senate Hearings Part $I 224$ (statement of Richard D. Godown). 
cally prevent consummation of the transaction. In certain instances, economic, commercial and financial conditions dictate proinpt action, and such delay could substantially interfere with the exercise of legitimate busmess opportunities." ${ }^{111}$ The problein raised by govcrnmental interference is that "mergers are neither all good nor all bad," 112 and "good" inergers may be thwarted along with the "bad." The inhibition or elimination of procoinpetitive inergers could have a detrimental effect on the important role of inergers and acquisitions of assets and capital stock im the capital allocation process. ${ }^{113}$

The possible harmful effect of premerger delay on the business commumity must be balanced against several countervailing considerations. First, the Act gives enforcenent agencies the power, in individual cases, to waive the waiting period. ${ }^{14}$ Insofar as any substantial burden is imposed on business by the thirty-day mandatory delay, that burden may be relieved-when the acquisition is lawful-by full and open cooperation with the antitrust enforcenent agencies, encouraging

111. House Hearings 193 (letter from the Association of the Bar of the City of New York). See also House Hearings 7 (statement of Rep. Seiberling); House Hearings 192 (statement of Thaddeus Holt) ("Undue prolongation of such a waiting period would kill an acquisition just as effectively as an automatic stay order issued by a court"); Senate Hearings Part I 223 (statement of Richard D. Godown); Shenefield \& Hartwell, Annual Survey of Antitrist Developments 1975-76, 34 WASH. \& LEE L. REv. 7, 17 (1977) ("Negotiations are frequently so dehicate that even the most minute delays can result in all sorts of unexpected problems"); MERGERs AND ACQUISITIONS, Fall 1976 , at 41 .

The Old Rules required notification 10 days after an agreement in principle was reached, which usually created a de facto waiting period. See text accompanying notes 104-05 supra. However, the Old Rules did not automatically delay transactions that might be aborted if a waiting period was required, as under the new program. See Senate Hearings Part III 73 (statement of Eleanor M. Fox).

112. Senate Report Part II 213 (quoting Milton Handler). See also Note, Preliminary Relief for the Government Under Section 7 of the Clayton Act, 79 HARv. L. Rev. 391,393 (1965).

113. "[Mergers] provide a mechanism whereby participants who choose to leave the market can do so, while new competitors can enter. Busmess founders can reap the rewards of their development efforts. Unsuccessful competitors can limit their losses. Diversified companies can release imefficient or unsuitable segments of their enterprises." Senate Hearings Part II 1033 (letter from Edward I. O'Brien). See Senate Report PART II 212 (minority views of Senators Eastland, McClellan, Hruska, Thurnond, Scott); Senate Hearings Part III 209-10 (letter from Peter H. Conze) ("An arbitrary waiting period will inhibit the free flow of capital in a somewhat depressed economy by deterring lawful inergers").

Mergers may serve another necessary economic function by permitting companies to economize on taxes through the merger of a company with high tax hability with one which has accuinulated large amounts of tax credits, thereby beuefitting both companies. Wall St. J., Jan. 30, 1976, at 10, col. 1, questioned in House Hearings 34 (statement of Paul Rand Dixou).

114. 15 U.S.C. $\$ 18 \mathrm{a}(\mathrm{b})(2)$ (1976). At least one commentator, however, does not regard the waiver provision as sufficient. Citing the "failing company doctrine" as an example of a situation where mergers could not move quickly enough under the new program, she stated that "although, of course, the antitrust authorities have discretion not to require the thirty-day waiting period-I do not think that is enough in certain emergency situations." Senate Hearings Part III 74-75 (statement of Eleanor M. Fox). 
thein to exercise their waiver power. For a business with nothing to hide, such a waiver could provide total protection from any harmful delays.

Second, delays of forty to 120 days have been considered reasonable and unlikely to cause serious business problems in practice. ${ }^{115}$ In hight of this, a thirty-day waitmg period should not be considered unreasonable.

Government requests for additional information will have adverse effects on perishable financial transactions only if the parties to the transaction have not anticipated such requests. The parties will presumably have engaged in extensive study of the proposed transaction and will thus be im the best position to know what information will be needed and the inost efficient ineans of inaking that information available to the government. Therefore, the parties conld file any additional relevant material at the same time as the initial notification and seek waiver of the waiting period, thereby avoiding any unnecessary delays. ${ }^{116}$

Lengthy delays resulting from government requests for additional information could also be eliminated in two other ways. First, the government could be required to make any requests for additional information or docuunents within a specified tinne after receiving the notification (a ten-day period has been suggested), or to relinquish its right to the discretionary time extension. ${ }^{17}$ However, no such requirement is found in the Act or the New Rules.

A second solution would require a hiberal judicial interpretation of the term "substantial comphance." The filing person must substantially comply with the notification prograin. However, the parties to the transaction should be able to ignore frivolous government requests

115. See House Hearings 106 (statement of Willard F. Mueller); id. 117 (statement of Kenneth G. Elzinga); Senate Hearings Part I 97 (statement of Thomas E. Kauper); id. 508 (statement of Joseph F. Brodley); 2 Merger Experts, supra note 98; Fox, What's in that Antitrust Bill? Power to Enforce Would Be Increased, N.Y. Times, Sept. 5, 1976, § 3, at 12, col. 3.

116. House Hearings 187 (letter from Timothy J. Shearer).

Potentially, a waiting period could be long, but if you represent the offering company, you have the power to prevent long delay. On the day you file the notification, you can call the government. If the acquisition is one that seems to present no antitrust problems at all, you may be able to get a waiver of the waitmg period from the government. If there is to be no waiver, you can ask the government-the FTC or Justice Department-what it will want in the way of additional documents and other infornation and you can do this on day one.

Bicks, Antitrust Aspects of Takeovers and Mergers: The Hart-Scott-Rodino Antitrust Improvement [sic] Act of 1976-A Panel, 32 Bus. LAw. 1517, 1524 (1977). See Goolrick, supra note 2, at 71; Shenefield \& Hartwell, supra note 111 , at 8.

117. Senate Hearings Part III 71 (statement of Eleanor M. Fox). See also SENATE REPORT PART II 211; House Hearings 193 (letter from Association of the Bar of the City of New York). 
for information not reasonably related to the potential anticompetitive effect of the transaction without risking failure to comply substantially with the requirements of the notification program. This interpretation would allow the transaction to be completed in such circumstances without incurring penalties for violation of the Act. ${ }^{118}$

While inost transactions will be subject to the thirty-day waiting period, the delay certainly should not be regarded as unreasonable. It is the waiting period that promises to make the new program more effective for antitrust enforcement purposes. Without the delay, mergers could be completed and the affairs of inerged busmesses become intermingled before the enforcement agencies could institute actions seeking preliminary injunctions. This would leave the government with resort only to historically inadequate, post-acquisition relief. For the first time, the inandatory waitmg period gives the agencies an opportunity to evaluate acquisitions prior to their consummation. The advantages in terms of more effective antitrust enforcement do indeed appear real.

The foreseeable benefits of the new prograin must be weighed against the potential adverse effects, in this case the risk of discouraging procoinpetitive mergers along with the anticompetitive ones. However, it is doubtful that the adverse effects on the busmess community caused by the thirty-day delay in consummating merger transactions will outweigh the antitrust benefits of the waiting period. Thirty days is not an unreasonable length of time, but in cases where the delay could present a hardship, cooperation by the merging firms could result in waiver of the waiting period. Furthermore, harmful delays associated with requests for additional information could be mitigated by legislative action limiting the time within which additional information could be requested or by a liberal judicial interpretation of "substantial compliance" that would permit the parties to ignore a government request for additional information where the request would be difficult to comply with or the information requested would be only marginally related to valid antitrust considerations.

Some commentators have gone so far as to predict that the new premerger notification program will ultimately prove beneficial to the legitimate interests of the busmess community by enhancing planning and predictability and by avoiding costly and time consuming litigation. ${ }^{119}$ Companies will be able more accurately to predict which transactions will be subject to review and will be in a position to make post-

118. See note 107 supra.

119. See Senate Report Part I 64-65 (quoting Thounas Kauper); Senate Hearings Part II 586 (letter from Rosemary M. Pooler). Shenefield \& Hartwell, supra note 111, at 18. 
acquisition changes with greater confidence than is possible at the present time.

\section{Disclosure.}

Unlike the Old Rules, which made the notification a part of the public record, ${ }^{120}$ the new premerger notification program specifies that material submitted on or with the notification form shall be exempt from disclosure under the Freedom of Information Act. ${ }^{121}$ As with most confidential business material, the possible disclosure of information to potential competitors represents a major concern to the corporate world.

Those who support nondisclosure claim that the information should be regarded as confidential and returned to the company supplying it at the conclusion of the investigation to prevent the government from maintaining dossiers on mdividual companies that would allow future government monitorimg. ${ }^{122}$ This argument, however, ignores the primary purpose of advance notification-providing government enforceinent agencies with sufficient information to enable thein to obtain a preliminary injunction against the consummation of an unlawful acquisition. The return of the information would impair the ability of the enforcement agencies to evaluate future reported acquisitions. By retaining the information, the agencies could conpare pending mergers with those involving the same companies, products or industry, and could make inore accurate assessinents of trends in mergers and acquisitions, thereby accelerating a final decison regarding the anticonipetitive unpact of a particular transaction. ${ }^{123}$

A more persuasive argunent einphasizes that a policy of nondisclosure may tend to mitigate the potentially harmful effects of the waiting period. Companies would not experience the same pressure to consumunate a merger in secrecy in order to avoid interference by com-

120. 39 Fed. Reg. $35,717,35,717$ (1974). See text accompanying note 69 supra.

121. 15 U.S.C. $\$ 18 \mathrm{a}(\mathrm{h})(1976)$. As if to alleviate further corporate concern over possible leaks of business information, the notification form itself states that "[a]ll information and documentary material filed in or with this form is confidential." 43 Fed. Reg. 33,552 (1978) (to be codified in 16 C.F.R. \& 803).

122. House Hearings 113-14 (statement of Rep. Cohen).

123. The FTC has commented:

Nothing in the language or legislative history of the act appears to prohibit the use of data submitted under the act for subsequent challenge to a reported acquisition or, in fact, for any other law enforcement purpose. A challenge after the waiting period might result from subsequent developments, such as additional acquisitions. Submitted material can also be useful in investigations and challenges to other acquisitions. To return the unaterials after the waiting period expires could seriously hinder later enforcement efforts.

43 Fed. Reg. 33,450, 33,518 (1978). 
petitors or other interested parties. ${ }^{124}$ The disclosure exemption does insure that minimal guarantees of secrecy will be observed, thereby alleviating corporate concern to some extent.

At least one commentator has argued in favor of disclosure of the notification information on the grounds that such disclosure is essential to effective evaluation of the new premerger program by Congress and the public. ${ }^{125}$ However, the Act specifically provides that "[n]othing in [the statute] is intended to prevent disclosure to either body of Congress or to any duly authorized committee or subcommittee of the Congress." 126 Furthermore, virtually all acquisitions become public upon coinpletion. Legal actions mstituted on the basis of information contained in the notification forms will also become a matter of public record. Therefore, it should not prove difficult to evaluate the new program on the basis of public information.

The true impact of the nondisclosure provision of the new premerger program is not yet settled. The new provision may prove less significant than an initial reading might suggest. While the Old Rules specifically provided that notification would be inade a part of the public record, no similar provision was included $\mathrm{m}$ the section dealing with Special Reports. The onnission was significant because the Special Report, rather than the notification letter, contamed the most confidential information. ${ }^{127}$ Thus, the amount of information that was subject to disclosure under the Old Rules may not be significantly greater than under the new program. ${ }^{128}$ Furthermore, much of the information subunitted may already be exempt ${ }^{129}$ from disclosure under the Freedom of Information Act, ${ }^{130}$ at least during the waiting period, as commercial busmess information falling within the investigatory exemption. ${ }^{131}$

On the other hand, there is a legitimate basis for corporate concern over the disclosure exemption. A question remams whether the exemption encoinpasses the fact of notification itself, or only the information contamed in the notification form. The Act speaks only of "any inforination or documentary inaterial filed." However, in many cases, disclosure of the inere fact of notification could trigger activity in the business commumity that would make the contemplated transaction un-

124. See note 111 supra and accompanying text.

125. Senate Hearings Part I 390 (statement of Mark Silbergeld).

126. 15 U.S.C. $\S 18 \mathrm{a}(\mathrm{h})(1976)$.

127. See text accoinpanying note 60 supra.

128. The notification letter would, however, alert competitors to the existence of a proposed merger or acquisition and thus trigger the problems that may be avoided under the nondisclosure provision.

129. Senate Hearings Part I 98 (statement of Thomas Kauper).

130. 5 U.S.C. $\$ 552(\mathrm{~b})$ (1976).

131. Id. $\S 552(\mathrm{~b})(7)$. 
profitable or even impossible. It will be the responsibility of the courts properly to construe the disclosure exemption to require confidentiality of the fact of notification itself. Such an interpretation would be beneficial to business interests because greater protection would be afforded to highly sensitive information. The FTC and the Antitrust Division would benefit indirectly because the greater assurance of confidentiality would encourage reporting firms to be more candid upon initial filing, thereby diminishing the need to request additional information and providing the agencies with a more complete record upon which to evaluate the transaction. ${ }^{132}$

\section{CONCLUSION}

The premerger notification programs were designed to provide antitrust enforcement agencies with more effective tools for halting unlawful transactions prior to their consummation. The effectiveness of the programs can be ineasured by balancing the benefits in terms of improved antitrust enforcement against the burdens imposed by the notification processes. Unfortunately, the Old Rules proved inadequate in providing preliminary relief against unlawful acquisitions and thus failed to achieve more effective enforcement of the antitrust laws. The Act and the New Rules represent an attempt to remedy some of the defects in the old program.

In general, the new premerger notification program seems likely to provide enforcement agencies with a reasonable opportumity to seek prehininary injunctions against the consummation of unlawful transactions. The most important contribution in this regard is the thirty-day waitmg period, which will enable the FTC and the Antitrust Division to evaluate proposed transactions and seek preliminary injunctions in appropriate cases. More detailed reporting in the notification form itself and the agencies' option to request additional information should lead to more accurate predictions of anticompetitive effects. Stiffer penalties should provide a more effective deterrent to unlawful actions. Finally, reliable guarantees of confidentiality should create a more cooperative relationship between the enforcement agencies and the business commumity.

The burdens imposed by the new program should also be consid-

132. The FTC's position on disclosure is as follows:

The Commission has taken the position not only that the contents of Notification and Report Forms and responses to requests for additional information are confidential but also that the fact of filing itself is a confidential matter. The statutory ban on disclosure specifically relates to disclosure to the public. The Commission, however, has taken no position on the issue whether the contents of a Hart-Scott-Rodino filing will be disclosed to other agencies.

Letter from Malcolın R. Pfunder, Assistant Director for Evaluation, FTC, to Jolın Titus (February 2,1979 ) (on file at Duke Law Journal office) (emphasis in original). 
ered. These burdens take on added significance in view of the expanded jurisdictional scope of the New Rules, which require inore firms to report a larger number of transactions. The antitrust benefits to be realized as a result of inore frequent reporting are questionable, and the expanded coverage may even prove harmful because any burdens created by the new program will be magnified. Retention of the old $\$ 250$ million criterion for reporting would probably have been wiser.

The possibility of lengthy delays associated with the waiting period provides the greatest cause for alarm. Such delays could diminish the number of procompetitive mergers in the business community. This possibility must be recognized and controlled. Waiver of the waiting period as a result of cooperation between reporting firms and the enforcement agencies and anticipation of government requests for additional information could serve to minimize the length of delays. Legislative or administrative limits on the time within which enforcement agencies could request additional information would tend to prevent abuse of the governmental privilege. Finally, a liberal judicial interpretation of "substantial compliance" would allow companies to disregard unreasonable government requests for additional information without incurring penalties.

Because highly sensitive busmess information may be contained in the notification form or submitted in response to requests for additional information, it is vital to the business community that such information remain confidential. The Act provides for this confidentiality, but stops slort of returning the submitted material to the reporting company. The question of whether the fact of notification will remain confidential has not yet been answered. Resolution of this question may well depend on the interpretation given to the Act's disclosure exemption by the courts. Since notification alone inay threaten the success of a proposed transaction, the courts should keep the fact of notification confidential.

Finally, post-acquisition relief has historically proven inadequate to guarantee a competitive economy. Premerger notification coupled with a inandatory waiting period appears to be a step in the right direction. The new premerger notification program promises greater success in enforceinent of the antitrust laws and, when tempered with proper planning and judicial interpretation, it is a success not tanited by the imposition of unreasonable burdens on government or the business community. 
